\title{
Effects of Oral Administration of Sodium Bicarbonate on Urine and Serum Mineral Concentrations in Sheep
}

\author{
Hideo Yano, Shoyo Sakurai and Ryoji Kawashima \\ Department of Animal Science, College of Agriculture, \\ Kyoto University, Kyoto-shi 606 \\ (Received July 11, 1977)
}

\begin{abstract}
The effects of sodium bicarbonate administration on blood acid-base balances and serum mineral concentrations were examined using three sheep in trial 1 . In trial 2 , six sheep were used, and the effects of sodium bicarbonate on urine and serum mineral concentrations were studied in sheep given low' and high calcium rations. As dietary sodium bicarbonate increased, blood $\mathrm{pH}$ and $\mathrm{H}_{2} \mathrm{CO}_{3}$ concentrations tended to become higher and blood $\mathrm{HCO}_{3}^{-}$concentrations and urine $\mathrm{pH}$ elevated significantly $(\mathrm{P}<0.05)$. Serum calcium concentrations had a trend to decrease and, adversely, serum phosphorus tended to increase as sodium bicarbonate was given. The administration of sodium bicarbonate had the effect of diminishing urine calcium concentrations and excretion. Urine phosphorus concentrations and excretion tended to increase and urine magnesium decreased by the administration of an alkalizing agent. It may be concluded that the decreases in urine calcium and magnesium were induced by an alkalotic condition of animal body, but urine phosphorus concentrations and excretion were not lowered by the feeding of an alkalizing agent. Therefore, sodium bicarbonate may have little effect in reducing the occurrence of urolithiasis.
\end{abstract}

The previous experiment ${ }^{1}$ ) showed that urine calcium and phosphorus concentrations had an intensively negative correlation with urine $\mathrm{pH}$ when a high concentrate ration was given to sheep. One of main causes of urolithiasis would be the elevation of urine phosphorus concentration ${ }^{1-5)}$. The fact was demonstrated in cattle ${ }^{6)}$ and sheep ${ }^{1.7 .8)}$ that urine phosphorus concentrations were increased by giving a high concentrate ration to animals. If the increase in urine phosphorus concentration is induced by only an acidic condition of animal body, the administration of alkalizing agent may decrease the urine phosphorus concentration.

On the other hand, OMORI et al. ${ }^{\text {9) }}$ described that a high phosphorus ration induced acidosis in goats. The addition of calcium carbonate to a ration appeared to reduce the phosphorus absorption from the gut of sheep ${ }^{10)}$.

The effects of sodium bicarbonate on blood acid-base balances and serum mineral concentrations were examined in the first trial and, in the second trial, the effects on urine and serum mineral concentrations were studied in sheep given low and high calcium rations.

\section{Materials and Methods}

Trial 1: Three sheep averaging about $40.3 \mathrm{~kg}$ in body weight were given rations respectively containing sodium bicarbonate $0,1.5$ and $3.0 \%$. The experimental design was a $3 \times 3$ latin square. After a 7-days preliminary period, blood and urine samples were obtained during the following 7 days in early winter.

Jap. J. Zootech. Sci., 49, (2): 104-109. 104

1978. 2. 
Adding Sodium Bicarbonate on Mineral Metabolism

Table 1. Composition of basal rations.*

\begin{tabular}{lcl}
\hline & \multicolumn{2}{c}{ Trial } \\
\cline { 2 - 3 } Ingredients & 1 & 2 \\
\hline Ground barley & $56 \%$ & $56 \%$ \\
Wheat bran & 24 & 24 \\
Rice straw & 19.5 & 20 \\
Calcium carbonate & 0.5 & - \\
\hline
\end{tabular}

* \% of air dry matter.

Table 2. Mineral composition of basal rations.*

\begin{tabular}{lll}
\hline \multirow{2}{*}{ Minerals } & \multicolumn{2}{c}{ Trial } \\
\cline { 2 - 3 } & \multicolumn{1}{c}{1} & \multicolumn{1}{c}{2} \\
\hline Calcium & $0.30 \%$ & $0.10 \%$ \\
Phosphorus & 0.45 & 0.53 \\
Magnesium & 0.15 & 0.22 \\
Sodium & 0.12 & 0.10 \\
Potassium & 0.88 & 1.00 \\
\hline
\end{tabular}

* \% of air dry matter.

Trial 2: Six sheep averaging about $47.0 \mathrm{~kg}$ in body weight were divided into two groups and fed for 20 days in midwinter. The low calcium group was given a ration containing $0.1 \%$ calcium and $0.6 \%$ phosphorus, and the high calcium group was fed with a ration containing $0.6 \%$ calcium and $0.6 \%$ phosphorus. Approximate level of calcium and phosphorus were achieved by the addition of calcium carbonate and disodium hydrogen phosphate. The low calcium group was given sodium bicarbonate at the level of $3.0 \%$ of the ration ( $\%$ of air dry matter basis) and the high calcium group was at the level of $1.5 \%$. The animals were fed for a 12-days control period and samples were taken during the last five days. Sodium bicarbonate was added for 8 days and urine and serum samples were taken during the last 3 days.

The composition of the basal ration and its mineral contents in both trials are shown in Tables 1 and 2. The ration was fed twice daily at the level of $1 \%$ of body weight. Sheep were placed in metabolism cages throughout the experimental period. Blood samples were taken from the jugular vein, and blood $\mathrm{pH}$ and $\mathrm{pCO}_{2}$ were immediately determined with a blood gas analyzer (Corning Company, Model 160). Calcium, magnesium, sodium and potassium in serum and urine were analyzed with an atomic absorption spectrophotometry. Inorganic phosphorus was determined by the method of FISKE-SubBarow ${ }^{11)}$. Urine samples were collected under toluene and urine minerals and urine $\mathrm{pH}$ were determined for each 24 hrs collection.

\section{Results}

Blood acid-base balances and urine $\mathrm{pH}$ in trial 1 are shown in Table 3 . By increasing the dietary sodium bicarbonate, blood $\mathrm{pH}$ values and $\mathrm{H}_{2} \mathrm{CO}_{3}$ concentrations tended to become higher though they were not significant. Blood $\mathrm{HCO}_{3}^{-}$concentrations and urine $\mathrm{pH}$ values significantly elevated when an alkalizing agent was added to a ration $(P<0.05)$. 
Table 3. Effects of sodium bicarbonate on blood acid-base balance and urine $\mathrm{pH}$. (Trial 1)

\begin{tabular}{lccc}
\hline \hline & \multicolumn{3}{c}{$\mathrm{NaHCO}_{3}(\%)$} \\
\cline { 2 - 4 } & 0 & 1.5 & 3.0 \\
\hline Blood values & & & \\
$\mathrm{pH}$ & $7.459 \pm 0.015^{*}$ & $7.485 \pm 0.010$ & $7.484 \pm 0.017$ \\
$\mathrm{H}_{2} \mathrm{CO}_{3}, \mathrm{mmoles} / l$ & $0.97 \pm 0.06$ & $1.00 \pm 0.10$ & $1.10 \pm 0.10$ \\
$\mathrm{HCO}_{3}^{-}, \mathrm{mEq} / l$ & $22.3 \pm 1.3^{\mathrm{a}}$ & $25.0 \pm 2.6^{\mathrm{ab}}$ & $27.8 \pm 2.7^{\mathrm{b}}$ \\
Urine $\mathrm{pH}$ & $7.1 \pm 0.5^{\mathrm{a}}$ & $8.0 \pm 0.1^{\mathrm{b}}$ & $8.2 \pm 0.2^{c}$ \\
\hline
\end{tabular}

* Standard deviation. $a, b$ and $c$ : Means with different superscript letters differ significantly $(\mathrm{P}<0.05)$.

Table 4. Effects of sodium bicarbonate on serum mineral concentrations. (Trial 1 )

\begin{tabular}{llll}
\hline & \multicolumn{3}{c}{$\mathrm{NaHCO}_{3}(\%)$} \\
\cline { 2 - 4 } & \multicolumn{1}{c}{0} & \multicolumn{1}{c}{1.5} & \multicolumn{1}{c}{3.0} \\
\hline Calcium, mEq/l & $5.2 \pm 1.2^{*}$ & $3.4 \pm 0.4$ & $3.4 \pm 0.5$ \\
Phosphorus, $\mathrm{mEq} / l$ & $5.6 \pm 0.2$ & $8.2 \pm 2.0$ & $8.0 \pm 1.0$ \\
Magnesium, $\mathrm{mEq} / l$ & $3.2 \pm 0.6$ & $3.1 \pm 0.3$ & $3.1 \pm 0.2$ \\
Sodium, mEq/l & $141 \pm 17$ & $129 \pm 30$ & $112 \pm 6$ \\
Potassium, mEq/l & $4.9 \pm 0.9$ & $4.7 \pm 0.1$ & $5.2 \pm 0.2$ \\
\hline
\end{tabular}

* Standard deviation.

Table 4 shows serum mineral concentrations in trial 1 . There was no large difference in all mineral concentrations. However, serum calcium tended to become lower and, adversely, serum phosphorus had a tendency to become higher with the increase of an alkalizing agent.

Table 5 represents the concentrations and excretion of urine minerals in trial 2. Urine $\mathrm{pH}$ values in the control period of the low calcium group were lower than those in the high calcium group $(\mathrm{P}<0.05)$. The addition of sodium bicarbonate tended to elevate the urine $\mathrm{pH}$ in both groups.

The administration of an alkalizing agent diminished the urine calcium concentration and excretion in both groups and, especially in the high calcium group, significantly decreased the urine calcium $(P<0.05)$. Compared with those of the high calcium group, urine concentrations and excretion of phosphorus were significantly high in the low calcium group $(P<0.05)$. Urine phosphorus tended to increase by the administration of sodium bicarbonate. Urine magnesium concentration and excretion, although not significant, tended to become lower with the addition of an alkalizing agent.

It is quite natural that the addition of sodium bicarbonate to rations was followed by the increase in urine sodium. Urine volume had a tendency to somewhat increase after the administration of this salt.

Serum mineral concentrations in trial 2 are shown in Table 6. Serum calcium became higher with the addition of calcium carbonate $(P<0,05)$ but seemed to lower with the feeding of an alkalizing agent. The decrease of serum calcium by the addition of sodium bicarbonate was near 
Adding Sodium Bicarbonate on Mineral Metabolism

Table 5. Effects of sodium bicarbonate on concentrations and excretion of urine minerals. (Trial 2)

\begin{tabular}{|c|c|c|c|c|}
\hline \multirow{2}{*}{$\begin{array}{l}\text { Group } \\
\text { Period }\end{array}$} & \multicolumn{2}{|c|}{ Low calcium } & \multicolumn{2}{|c|}{ High calcium } \\
\hline & Control & $+\mathrm{NaHCO}_{3}$ & Control & $+\mathrm{NaHCO}_{3}$ \\
\hline \multicolumn{5}{|c|}{ Urine concentration, $\mathrm{mEg} / l$} \\
\hline Calcium & $0.3 \pm 0.1^{* a}$ & $0.2 \pm 0.1^{a}$ & $0.6 \pm 0.2^{b}$ & $0.4 \pm 0.1^{\mathrm{a}}$ \\
\hline Phosphorus & $113.0 \pm 19.2^{\mathrm{a}}$ & $126.4 \pm 25.4^{\mathrm{a}}$ & $62.0 \pm 27.6^{\mathrm{b}}$ & $78.8 \pm 16.0^{\mathrm{b}}$ \\
\hline Magnesium & $31.1 \pm 9.9$ & $22.1 \pm 7.2$ & $35.2 \pm 10.7$ & $25.4 \pm 7.7$ \\
\hline Sodium & $47.8 \pm 6.6^{c}$ & $132.6 \pm 26.2^{d}$ & $54.3 \pm 7.0^{\circ}$ & $102.2 \pm 24.5^{d}$ \\
\hline Potassium & $130.7 \pm 40.5$ & $109.2 \pm 23.4$ & $123.0 \pm 15.6$ & $142.2 \pm 30.0$ \\
\hline \multicolumn{5}{|c|}{ Urince excretion, $\mathrm{mg} /$ day } \\
\hline Calcium & $4.8 \pm 0.8^{a}$ & $4.4 \pm 0.8^{\mathrm{a}}$ & $6.2 \pm 1.0^{b}$ & $4.8 \pm 0.6^{\mathrm{a}}$ \\
\hline Phosphorus & $1525 \pm 348^{\mathrm{a}}$ & $1850 \pm 446^{\mathrm{a}}$ & $521 \pm 277^{b}$ & $838 \pm 248^{b}$ \\
\hline Magnesium & $278 \pm 78$ & $258 \pm 84$ & $228 \pm 83$ & $180 \pm 66$ \\
\hline Sodium & $821 \pm 132^{c}$ & $3178 \pm 594^{\mathrm{d}}$ & $717 \pm 128^{c}$ & $1497 \pm 286^{d}$ \\
\hline Potassium & $3662 \pm 923$ & $4217 \pm 1164$ & $2825 \pm 628$ & $3363 \pm 837$ \\
\hline Urine $\mathrm{pH}$ & $6.8 \pm 0.4^{\mathrm{a}}$ & $7.6 \pm 0.3^{b}$ & $7.3 \pm 0.3^{b}$ & $7.7 \pm 0.4^{b}$ \\
\hline Urine volume, $\mathrm{m} l$ & $774 \pm 205$ & $1014 \pm 381$ & $585 \pm 197$ & $626 \pm 167$ \\
\hline
\end{tabular}

* Standard deviation. a and b: Means with different superscript letters differ significantly $(P<0.05)$. $\quad c$ and $d:$ Means with different superscript letters differ significantly $(P<0.01)$.

Table 6. Effects of sodium bicarbonate on serum mineral concentrations. (Trial 2)

\begin{tabular}{|c|c|c|c|c|}
\hline \multirow{2}{*}{$\begin{array}{l}\text { Group } \\
\text { Period }\end{array}$} & \multicolumn{2}{|c|}{ Low calcium } & \multicolumn{2}{|c|}{ High calcium } \\
\hline & Control & $+\mathrm{NaHCO}_{3}$ & Control & $+\mathrm{NaHCO}_{3}$ \\
\hline Calcium, $\mathrm{mEq} / l$ & $3.7 \pm 0.4^{* a}$ & $3.7 \pm 0.4^{\mathrm{a}}$ & $4.7 \pm 0.3^{b}$ & $4.1 \pm 0.4^{\mathrm{ab}}$ \\
\hline Phosphorus, mEq/l & $6.6 \pm 0.4$ & $6.8 \pm 0.8$ & $6.2 \pm 0.8$ & $6.4 \pm 0.6$ \\
\hline Magnesium, $\mathrm{mEq} / l$ & $3.0 \pm 0.2$ & $3.2 \pm 0.3$ & $3.0 \pm 0.3$ & $3.2 \pm 0.2$ \\
\hline Sodium, $\mathrm{mEq} / l$ & $170 \pm 23$ & $169 \pm 24$ & $173 \pm 20$ & $165 \pm 27$ \\
\hline Potassium, $\mathrm{mEq} / l$ & $5.4 \pm 0.6$ & $5.1 \pm 0.7$ & $5.4 \pm 0.7$ & $4.9 \pm 0.5$ \\
\hline
\end{tabular}

* Standard deviation. a and $\mathrm{b}$ : Means with different superscript letter differ significantly $(\mathrm{P}<0.01)$.

the significance in the high calcium group. No obvious difference was found in the serum phosphorus, magnesium, sodium and potassium concentrations when an alkalizing agent was given.

\section{Discussion}

Although not significant, serum calcium concentrations tended to decrease when an alkalizing agent was added to rations in both trials. Similar results were also obtained by HoAr et al. ${ }^{5}$. PAYNE et al. ${ }^{12)}$ described that diets made alkaline with sodium carbonate decreased the exchangeable pool of calcium in the blood of goats and cows. It has been recently shown by VERDARIS et al. ${ }^{13)}$ that the apparent absorption and retention of calcium were lower in cattle given high $\mathrm{pH}$ diets than those in cattle fed low $\mathrm{pH}$ diets. However, it is not yet clear whether the decrease in serum calcium may be induced by the reduction of calcium from the gut or the change of bone metabolism. 


\section{YaNo, SAKURAI and KaWASHIMA}

Adversely, in trial 1, serum phosphorus concentrations showed a trend to increase as sodium bicarbonate was given to sheep. As shown in the results that serum phosphorus concentrations were decreased by oral administration of calcium carbonate ${ }^{14,15}$, the change of serum phosphorus concentrations might be associated with the alteration of serum calcium.

The increase in urine calcium concentrations was observed when urine $\mathrm{pH}$ were lowered by giving a high concentrate ration ${ }^{1)}$ or ammonium chloride to sheep ${ }^{16}$. In this experiment, urine concentrations and excretion of calcium were lowered by the addition of an alkalizing agent. MARTIN and JoNES ${ }^{17)}$ also observed similar results in the experiment using humans. It may be concluded that urine concentrations and excretion of calcium, which increase under acidic condition of the animal body, decrease by the administration of an alkalizing agent.

Although a larger amount of sodium bicarbonate was given to sheep in the low calcium group than in the high calcium group, urine mineral excretion were obviouly more affected in the latter group than in the former group. This result might be induced from the condition of sheep in the low calcium group, which were more acidic, in comparison to that in the high calcium group. Urine $\mathrm{pH}$ values in sheep given a low calcium ration were lower than those in sheep fed with a high calcium ration.

OMORI et al. ${ }^{97}$ indicated that a high phosphorus ration-phytate type-induced the acidosis in goats. On the other hand, phosphorus absorption from the gut was likely to be decreased by the addition of calcium carbonate ${ }^{10}$. The different urine $\mathrm{pH}$ values between low and high calcium rations may depend on different amounts of phosphorus absorbed from the intestine.

In the previous experiment ${ }^{11}$, the urine phosphorus concentration increased and, simultaneously, the urine $\mathrm{pH}$ lowered when a high concentrate ration was given to sheep. In this experiment, such a reciprocal association was not found in sheep given an alkalizing agent. Urine phosphorus concentrations tended to become higher whereas urine $\mathrm{pH}$ values were elevated by the administration of sodium bicarbonate. The result suggests that the elevation of uring phosphorus concentration in ruminants given a high concentrate ration may not be necessarily due to an acidic condition of animal body.

HOAR et al. ${ }^{5)}$ reported that the feeding of sodium bicarbonate stimulated the formation of urinary calculi through the increase of urine alkalinity in lambs fed an all-concentrate diet. From the result that the decrease in urine phosphorus concentration was not observed in speep fed with an alkalizing agent, it is considered that the administration of sodium bicarbonate does not predispose to decrease the incidence of urolithiasis but may become a cause of calculi formation.

SASAKI et al. ${ }^{18)}$ observed that the decrease in urine pH and the increase in urine magnesium concentration occurred simultaneouly during eating in sheep. An intensively negative correlation was also found between urine $\mathrm{pH}$ and urine magnesium in beef cattle fed with a high concentrate ration ${ }^{19)}$. Urine concentrations and excretion of magnesium, although not significant, showed a trend to decrease when sodium bicarbonate was administered. Similar to urine calcium, urine concentrations and excretion of magnesium would be closely correlated with urine $\mathrm{pH}$, that is, an acid-base balance in animal body.

\section{References}

1) Yano, H. and R. Kawashima, Jap. J. Zootech. Sci., 47: 104-109. 1976.

2) Bushman, D. H., L. B. Embry and R. J. Emerick, J. Anim. Sci., 26: 1199-1204. 1967.

3) Packett, L.V. and J.P. Hauschild, J. Nutr., 84: 185-190. 1964.

4) Robbins, J. D., H. O. Kunkel and H. R. Crookshank, J. Anim. Sci., 24: 76-82. 1965. 
5) Hoar, D. W., R. J. Emerick and L. B. Embry, J. Anim. Sci., 29: 647-652. 1969.

6) Reed, W. D.C., R. C. Elliot and J.H. Topps, Nature, 208: 953-954. 1965.

7) Terashima, Y., I. Shinozaki, N. Tohrai and H. Itoh, Jap. J. Zootech. Sci., 46: 263-268. 1975.

8) Yamo, H., K. Miroshi and R. Kawashima Jap. J. Zootech. Sci., 47: 270-276. 1976.

9) Omori, S., H. Ito and T. NaKa jima, Bull. Nat. Inst. Agr. Sci., No. 15: 41-48. 1958.

10) Yano, H., H. Matsui and R. Kawashima, Jap. J. Zootech. Sci., 46: 49 (supplement). 1975.

11) Fiske, C. H. and Y. Subbarow, J. Biol. Chem., 66: 375-400, 1925.

12) Payne, J. M., S. M. Dew, R. Manston and M. J. VagG, Physiology of Digestion and Metabolism in the Ruminant 584-598. Oriel Press. Newcastle. England. 1970.

13) Verdaris, J. H. and J.L. Evans, J. Dairy Sci., 59: 1271-1277. 1976.

14) Wise, M. B., A. L. DrdovezA and E. R. Barrick, J. Nutr., 79: 79-84. 1963.

15) Sato, K., K. Kagota, S. Matsuo and S. Kinoshita, Bulltin of the Takikawa Animal Husbandry Experimental Station, No. 5: 8-12. 1967.

16) Yano, H., R. Kawashima and S. Uesaka, Memoirs of the College of Agriculture, Kyoto Univ., 101: 27-34. 1972.

17) Martin, H.E. and R. Jones, Am. Heart. J., 62: 206-210. 1961.

18) SaSaki, Y., S. Watanabe, Y. Satoh and S. Kato, Jap. J. Zootech. Sci., 46: 208-212. 1975.

19) Unpublished data.

\title{
重炭酸ナトリウムの経口投与がめん羊の尿， 血清中ミネラル濃度に及ぼす影響
}

\author{
天野秀雄・桜并從容・川島良治 \\ 京都大学農学部畜産学科, 京都市 606
}

第 1 試験では 3 頭のめえ羊を用いて重炭酸ナトリゅム 投与が血液中酸塩基平衡と血清中ミネラル淟度に及注主 影響について検討した。符 2 試験では，低カルシウム飼 料と高カルシウム飼料学給与しためん羊各 3 頭に重炭酸 ナトリウムを給与した場合の尿および血清中ミネラル濃 度の变化を調べた．重炭酸ナトリウム投与により，血液 $\mathrm{pH}$ および $\mathrm{H}_{2} \mathrm{CO}_{3}$ 濃度は上昇の倾向があり：血液中 $\mathrm{HCO}_{3}$ - 濃度は有意に增加した $(\mathrm{P}<0.05)$. また血清中 カルシウム濃度は低下，血清中りン浱度は增加の傾向が
見られた。重炭酸ナトリウム投与は尿中カルシウムとマ グネシウムの嶩度および排泄量を隇少させ，尿中リンの 䟴度および排泄量を增加させる傾向にるった．以上のこ とから，体液がフルカリ性の状態に傾くと尿中カルシウ ムとマグネシウムの浱度および排泄量は減少するが，尿 中リンはそのよらな变化を示さないるのと考えられる。 さらにアルカリ剂（重炭酸ナトリウム）の投与浪結石 症の発生防止には有剂でないことが示唆された。 